\title{
Ribotoxic stress by mycotoxins
}

\author{
J. D. Stewart $\cdot$ H. M. Bolt $\cdot$ J. G. Hengstler
}

Published online: 21 August 2010

(C) Springer-Verlag 2010

More than $10 \%$ of the world's annual harvests are destroyed by mold (Normile 2010). Many fungi produce mycotoxins that accumulate in human tissues and induce toxic effects (Muñoz et al. 2009; Degen et al. 1997; Magdalan et al. 2009; Degen and Hengstler 2008; Klarić et al. 2008; Huang et al. 2009). The best known mycotoxin is aflatoxin $B_{1}$, which is one of the strongest human liver carcinogens (Hengstler et al. 1999; Hewitt et al. 2007). Aflatoxin $B_{1}$ is particularly critical for humans as they lack efficient detoxification of aflatoxin $\mathrm{B}_{1}$ epoxide which is generated in the liver (Degen and Neumann 1978, 1981). In contrast, many mouse strains express specific isoforms of glutathione-S-transferase which detoxify aflatoxin $B_{1}$ metabolite and - in contrast to humans-render mice resistant to aflatoxin B1 toxicity.

Besides aflatoxin, mycotoxins have not obtained the widespread attention and publicity that they deserve. Relatively, little is known about the outbreaks of severe gastroenteritis in China, the largest affecting 130,000 people, which were caused by rain-damaged wheat products (Pestka 2010, this issue). Mycotoxins in food are certainly having a major input on life spans in developing countries (Normile 2010).

The editors are happy that Professor James J. Pestka from Michigan State University accepted our invitation and has contributed a review about the mechanisms of action, human exposure and toxicological relevance of trichothec-

J. D. Stewart $(\bowtie) \cdot$ H. M. Bolt · J. G. Hengstler Leibniz-Institut für Arbeitsforschung an der TU Dortmund (IfADo), Leibniz Research Centre for Working Environment and Human Factors, Ardeystrasse 67, 44139 Dortmund, Germany e-mail: stewart@ifado.de enes and specifically the most relevant deoxynivalenol (DON) (Pestka 2010, this issue). DON is the most commonly detected trichothecene in cereal grains and was responsible for numerous large outbreaks of human gastroenteritis. DON acts by interference with both translation and activation of protein kinases, representing toxic mechanisms that are cutting-edge topics of our journal (Muguruma et al. 2008; Glahn et al. 2008; Hengstler and Bolt 2008a, b; Decker et al. 2009; Periyakaruppan et al. 2009; Ito et al. 2009).

Of particular interest is DON's action as a "ribotoxin", where protein kinases are mobilized to the ribosome and subsequently phosphorylated. This review is a must-read for everyone interested in mycotoxins and toxicity mediated via compromised ribosomes.

\section{References}

Decker M, Arand M, Cronin A (2009) Mammalian epoxide hydrolases in xenobiotic metabolism and signalling. Arch Toxicol 83:297318

Degen GH, Hengstler JG (2008) Developments in industrial and occupational toxicology: REACH, toxicogenomics, mycotoxins, lead, asbestos, boron, bitumen, deletions polymorphisms and SNP interactions: meeting report of the 16th EUROTOX training and discussion session. Arch Toxicol 82:483-487

Degen GH, Neumann HG (1978) The major metabolite of aflatoxin B1 in the rat is a glutathione conjugate. Chem Biol Interact 22:239 255

Degen GH, Neumann HG (1981) Differences in aflatoxin B1-susceptibility of rat and mouse are correlated with the capability in vitro to inactivate aflatoxin B1-epoxide. Carcinogenesis 2:299-306

Degen GH, Gerber MM, Obrecht-Pflumio S, Dirheimer G (1997) Induction of micronuclei with ochratoxin A in ovine seminal vesicle cell cultures. Arch Toxicol 71:365-371

Glahn F, Schmidt-Heck W, Zellmer S, Guthke R, Wiese J, Golka K, Hergenröder R, Degen GH, Lehmann T, Hermes M, Schormann W, Brulport M, Bauer A, Bedawy E, Gebhardt R, Hengstler JG, 
Foth H (2008) Cadmium, cobalt and lead cause stress response, cell cycle deregulation and increased steroid as well as xenobiotic metabolism in primary normal human bronchial epithelial cells which is coordinated by at least nine transcription factors. Arch Toxicol 82:513-524

Hengstler JG, Bolt HM (2008a) Oxidative stress: from modification of cell-cycle related events, secondary messenger function, dysregulation of small GTPases, protein kinases and phosphatases to redox-sensitive cancer models. Arch Toxicol 82:271-272

Hengstler JG, Bolt HM (2008b) Loss of DNA damage checkpoint genes: switch from preferential induction of point mutations to chromosomal damage precedes the transition towards an aggressive cancer type. Arch Toxicol 82:341-342

Hengstler JG, Van der Burg B, Steinberg P, Oesch F (1999) Interspecies differences in cancer susceptibility and toxicity. Drug Metab Rev 31:917-970

Hewitt NJ, Lechón MJ, Houston JB, Hallifax D, Brown HS, Maurel P, Kenna JG, Gustavsson L, Lohmann C, Skonberg C, Guillouzo A, Tuschl G, Li AP, LeCluyse E, Groothuis GM, Hengstler JG (2007) Primary hepatocytes: current understanding of the regulation of metabolic enzymes and transporter proteins, and pharmaceutical practice for the use of hepatocytes in metabolism, enzyme induction, transporter, clearance, and hepatotoxicity studies. Drug Metab Rev 39:159-234

Huang B, Xiao H, Zhang J, Zhang L, Yang H, Zhang Y, Jin J (2009) Dual-label time-resolved fluoroimmunoassay for simultaneous detection of aflatoxin B1 and ochratoxin A. Arch Toxicol 83:619624
Ito M, Nakagawa H, Okada T, Miyazaki S, Matsuo S (2009) ER-stress caused by accumulated intracistanal granules activates autophagy through a different signal pathway from unfolded protein response in exocrine pancreas cells of rats exposed to fluoride. Arch Toxicol 83:151-159

Klarić MS, Rumora L, Ljubanović D, Pepeljnjak (2008) Cytotoxicity and apoptosis induced by fumonisin $\mathrm{B}(1)$, beauvericin and ochratoxin A in porcine kidney PK15 cells: effects of individual and combined treatment. Arch Toxicol 82:247-255

Magdalan J, Ostrowska A, Podhorska-Okołów M, Piotrowska A, Izykowska I, Nowak M, Dolińska-Krajewska B, Zabel M, Szelag A, Dziegiel P (2009) Early morphological and functional alterations in canine hepatocytes due to alpha-amanitin, a major toxin of Amanita phalloides. Arch Toxicol 83:55-60

Muguruma M, Arai K, Moto M, Nishimura J, Dewa Y, Mitsumori K (2008) Piperonyl butoxide activates c-Jun and ATF-2 in the hepatocytes of mice. Arch Toxicol 82:749-753

Muñoz K, Blaszkewicz M, Degen GH (2009) Simultaneous analysis of ochratoxin A and its major metabolite ochratoxin alpha in plasma and urine for an advanced biomonitoring of the mycotoxin. J Chromatogr B Anal Technol Biomed Life Sci [Dec 3, Epub ahead of print]

Normile D (2010) Spoiling for a fight with mold. Science 327:807

Periyakaruppan A, Sarkar S, Ravichandran P, Sadanandan B, Sharma CS, Ramesh V, Hall JC, Thomas R, Wilson BL, Ramesh GT (2009) Uranium induces apoptosis in lung epithelial cells. Arch Toxicol 83:595-600 